\title{
Restoring human freedoms: from utilitarianism to a capability approach to wetland restoration in Louisiana's coastal master plan
}

\author{
David O'Byrne'
}

Accepted: 12 December 2021 / Published online: 18 January 2022

(c) The Author(s) 2022

\begin{abstract}
Coastal restoration is being undertaken globally to address and avoid the losses caused by rising relative sea levels and other forms of coastal ecosystem degradation. Restoration decision-making is increasingly considering its social impacts, but how social factors should be incorporated in decision-making is a matter of debate. Multi-criteria approaches are promoted for their ability to overcome problems associated with monetary valuation of nature. Louisiana's coastal restoration program has been promoted as a good example of a multi-criteria approach. This article engages in a critical examination of the wetland restoration program contained in Louisiana's 2017 Coastal Master Plan (CMP). The principles that underlie decisionmaking, and how these principles are deployed through decision tools and metrics, constitute an implicit utilitarianism. This utilitarianism, in spite of the use of multiple criteria, recreates problems commonly associated with monetary valuation, namely, it creates poor distributional outcomes and fails to account for non-economic values of nature. The study argues that these problems can be overcome with a systematic use of the capability approach. This would involve the development of an evaluative framework that prioritizes the freedoms of the worst-off, and translation of this framework into a series of metrics compatible with planning models and tools. The paper closes by outlining some challenges to achieving a capability approach in Louisiana's CMP.
\end{abstract}

Keywords Amartya Sen $\cdot$ Coastal management $\cdot$ Coastal restoration $\cdot$ Multi-criteria decision-analysis $\cdot$ Social choice

\section{Introduction}

Rising sea levels and the continuing expansion of the built environment are putting coastal wetlands under pressure globally, especially in river deltas (Giosan et al., 2014; Syvitski et al., 2009; Tessler et al., 2015; Wright et al., 2019). One possible response to this problem is to restore degraded wetlands. Studies from around the world chart the increased investment in coastal restoration, while calling for upscaling and improved restoration techniques. At the same time, lessons to guide future restoration are starting to accrue (Bayraktarov et al., 2016; Liu et al., 2016). One major challenge is that the criteria directing wetland restoration have commonly been purely ecological, aiming to restore ecological integrity and resilience (Martin \& Lyons, 2018; Zhang et al., 2020). Recently, the recognition of human

David O’Byrne

david.obyrne@lucsus.lu.se

1 Lund University Centre for Sustainability Studies, Lund, Sweden dependence on wetland ecosystems has led to calls for the inclusion of social criteria in restoration projects (Dufour \& Piégay, 2009; Martin \& Lyons, 2018). It is an ongoing subject of debate as to what these criteria should be and how to integrate them in decision-making.

The question of how to include social values of nature in restoration projects is part of the broader debate about how to assess the social benefits of the environment. This has been a central problem in discussions over sustainable development (Boda \& Faran, 2018; Sen, 2004; Solow, 1993) and the valuation of ecosystem services (Gómez-Baggethun \& Ruiz-Pérez, 2011). There is a major effort within this literature to move beyond the purely economic, or monetary, valuation of natural assets, due to its perceived limitations on two points in particular. These are as follows: (i) it fails to accommodate the range of ways in which nature is valued (Gómez-Baggethun \& Ruiz-Pérez, 2011; Sen, 2004), and (ii) because monetary valuation is generally related to income, it creates poor distributional outcomes (Boda \& Faran, 2018; Gómez-Baggethun \& Ruiz-Pérez, 2011). One suggestion for how to move beyond economic valuation, at the practical 
level, is to use multiple criteria. There is an extensive literature on this in the field of multi-criteria decision analysis (MCDA) (Martin \& Mazzotta, 2018; Martin et al., 2018; Marttunen et al., 2015; Saarikoski et al., 2016).

Louisiana's coastal restoration plan, part of its Coastal Master Plan (CMP) (CPRA, 2017b), has been touted as an excellent example of multi-criteria restoration planning. Its multi-criteria approach is praised for its ability to engage multiple stakeholders, improve transparency, and elevate non-market considerations (Ellen et al., 2016). At the same time, concerns have been raised about the distribution of the negative impacts of the plan, especially on fishers and seafood workers (Lewis \& Ernstson, 2017). These impacts are expected to be both monetary and non-monetary. This suggests that the CMP might be failing to overcome the issues commonly associated with economic valuation.

In light of this, this study aims to investigate whether the use of multi-criteria decision-making in the CMP recreates the problems associated with monetary valuation, and if it does so, to propose a means for overcoming these issues. The primary contribution of this article is in the form of recommendations for the coastal planning process in Louisiana, which will produce a revised CMP in 2023. The article makes a secondary contribution in the form of insights for the practice of multi-criteria-driven restoration generally. Whereas much of the literature on MCDA tends to focus on methods for combining or aggregating preferences or values in participatory decision-making processes (Martin \& Mazzotta, 2018; Martin et al., 2018; Marttunen et al., 2015; Saarikoski et al., 2016), the approach presented here entails a normative argument, drawing on Amartya Sen's critique of utilitarianism, for what values should be included in such a process (Sen, 1999b). Drawing on Sen's capability approach (Sen, 2001), I argue for the use of objectively measureable substantive human freedoms or capabilities, as the criteria for restoration decision-making. It is likely that other MCDA processes that do not clearly articulate an underlying normative theory will recreate the socially dominant approach, which in many cases will be utilitarian. This paper therefore encourages researchers studying environmental decision-making processes to both identify the implicit normative framework in operation in their cases of interest and to consider a capability approach as an alternative when utilitarianism is identified.

A number of authors have proposed the capability approach as a guiding approach for multi-criteria decisionmaking. For example, Kolinjivadi et al. (2015) argue that payments for ecosystem services should be directed to capabilities expansion. Similarly, Pelenc and Etxano (2021) operationalize a multi-criteria evaluation, based on the capability approach, in collaboration with a social movement. In one key study, Boda (2018) has argued for a capability approach to beach restoration in a small coastal Florida town. The current study is novel, as far as the author is aware, in arguing that the capability approach is an appropriate guide for multi-criteria decision-making in large-scale coastal wetland restoration.

Theoretically speaking, the ambition of this paper is to show how the capability approach overcomes flaws and contradictions inherent to the utilitarian approach in coastal planning. This immanent approach (Boda \& Faran, 2018) contrasts with an external form of critique whereby the capability approach would be used as a framework for judging the effects of utilitarianism. The method of presentation in the paper follows this immanent logic: it begins by identifying utilitarianism as the implicit normative approach, and showing the tensions and problems it creates. The capability approach is then introduced as an approach that can overcome these problems.

The next section introduces Louisiana's $\$ 50$ billion CMP (CPRA, 2017b). This is followed by a critical evaluation of the multi-criteria decision-making it employs, using qualitative methods. This analysis shows that the decision-making process is undergirded by economic utilitarianism, which recreates the issues usually associated with monetary valuation, namely poor distributional outcomes and significant non-monetary losses. The discussion section argues that the capability approach can overcome these issues and is equally compatible with multi-criteria decision-making. Finally, practical steps, and some barriers, towards introducing a capability approach to the CMP are outlined.

\section{Restoration in Louisiana's Coastal Master Plan}

To combat land loss in the Mississippi River Delta, Louisiana's Coastal Protection and Restoration Authority (CPRA) produces a CMP every 6 years (previously every five years), with the latest being published in 2017 (CPRA, 2017b). The plan coordinates the construction of large structural projects for protection and restoration and combines MCDA with deliberative planning (Groves et al., 2017). The 124 projects included in the current CMP, to be implemented over the next 50 years, were selected from a wider set of proposed projects. The funding of $\$ 50$ billion is split evenly between restoration and protection projects. The process is organized through a planning tool, which aggregates ecosystem models and employs an algorithm to select a suite of restoration projects based on their combined performance according to a range of metrics (Groves et al., 2017). The CPRA and a framework development team, a participatory body of 60 members from business, government, civil society, and academia, developed these metrics (Ellen et al., 2016).

For both kinds of projects (protection and restoration), there is a primary criterion called a decision driver. For restoration projects, the decision driver is land area built or maintained at 50 years, measured in acres, and for protection 
projects, it is reduction in expected annual damage (EAD), measured in dollars. The general approach is to start by maximizing performance in terms of the decision drivers, and then to test and adjust according to the other metrics (Groves et al., 2017). The two main types of restoration projects are marsh creation projects, using dredged sediment, and sediment diversions. Sediment diversions involve the construction of controlled openings in the levee of the Mississippi River. These are designed to introduce sediment-rich river water into areas of the delta that have been starved of sediment, due to historical river engineering works, including the construction of levees (Day et al., 2018). Much of this paper will focus on the decision-making behind, and expected impacts of, two proposed sediment diversions, the Mid-Barataria and Mid-Breton Sound sediment diversions. These will be constructed downriver of New Orleans, one in the east bank and one in the west bank of the river (visible in Fig. 1 at 'Jean Lafitte').

\section{Materials and methods}

Methodologically, this study begins by testing the hypothesis that utilitarianism underlies the decision-making processes in the CMP. This hypothesis was formulated based on preliminary examination of the CMP and theory of economic decision-making (Atkinson, 1999, 2009; Boda \& Faran, 2018; Faran, 2010). Atkinson (1999) argues that "(a) lthough few economists today openly admit to being utilitarian, implicit assumptions of this kind underlie many policy prescriptions" p. 175. Utilitarianism, in the context of economic decision-making, is characterized by three elements. Decisions are judged on (i) the end state of affairs, meaning (ii) the welfare of the entire society in terms of individual utility, and (iii) this is measured as the sum of individual utilities (Atkinson, 1999). In utilitarian decision-making, utility is related to monetary measures, like income and wealth, and therefore the sum total of utilities is measured through aggregate indicators of wealth like GDP (Ortega Landa, 2004). Utilitarian decision-making aims to maximize GDP as a way of improving the general welfare.

The hypothesis is tested using two data-sets. The first (qualitative data-set) consists of data gathered through qualitative research - involving interviews, non-participant observation, and document analysis - to identify the key principles underlying decision-making. The second (technical data-set) is data gathered from technical documents, which are interrogated to reveal whether, and subsequently how, the use of metrics and formal decisions support particular key principles of utilitarianism. These two types of data are complementary in triangulating a response to the hypothesis. The technical documents reveal what concrete
Fig. 1 Southeast Louisiana, showing the location of the City of New Orleans the location of proposed sediment diversions and the area of influence of diversions (Source-adapted from CPRA 2017a, 2017b: Public Domain)

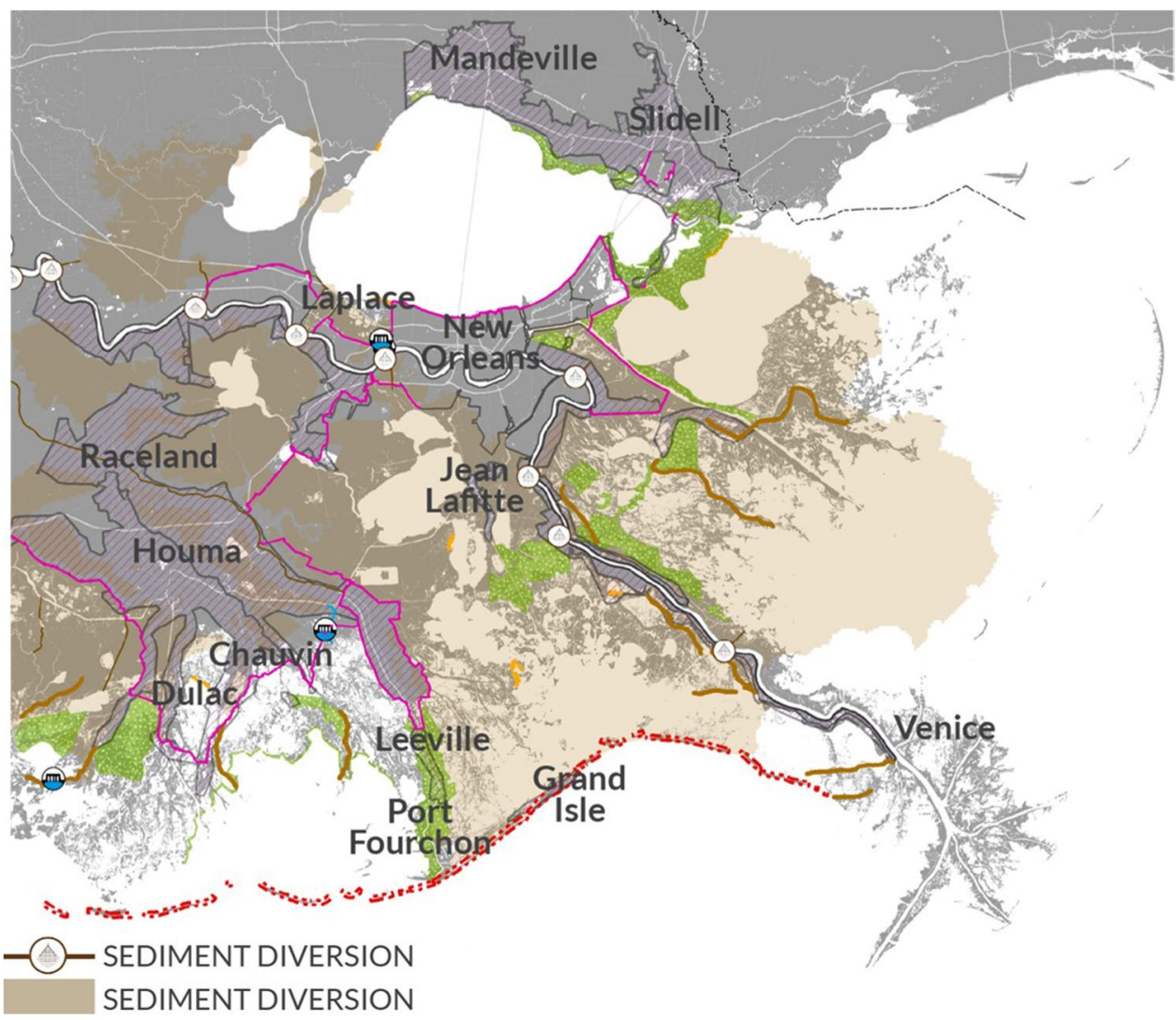


decisions were made in the formal planning process, but may not reveal tacit decisions that are made outside the formal documented planning process. On the other hand, interviews and other qualitative methods can reveal what happens "behind the scenes" but is subject to the fallibility of the participants. The results of this analysis are presented in the "Principles behind decision-making" and "Analysis of technical documents" sections of this paper. The study goes on to discuss the possible impacts of the utilitarian approach in the CMP's coastal restoration program, presented in the "Utilitarianism and its impacts" section. This argument is informed by further interviews, theory, and literature.

Data were collected during 8 months of fieldwork, which took place between 2017 and 2019, using predominantly qualitative methods, and complemented with prior and subsequent deskwork. This fieldwork was undertaken as part of a larger PhD project (O'Byrne, 2020), in which the conceptual model, informed by welfare and development economics (Atkinson, 1999; Sen, 2001), characterized coastal restoration planning as an attempt at sustainable development (Boda \& Faran, 2018). Table 1 presents the various methods and techniques used to collect and analyze the data in the two data-sets, and how they relate to the findings of the paper.

\section{Data collection and sampling}

Interviews were semi-structured expert interviews and interview participants were purposively sampled, with some subsequent snowball sampling. Customized interview guides were prepared for each interview, to target the particular expertise of the participant. Ten interviews focused on the decision-making process for the CMP and the economic thinking that it entailed, and eleven interviews focused on the impacts of coastal change and the CMP, on fishers in particular, in economic, social, and ecological terms. Interviews were recorded with an audio voice recorder, where permitted by the interviewee, and transcribed. Otherwise, extensive hand-written notes were taken. Meetings (detailed in Table 1.) were attended in person by the author and handwritten notes were taken. All meetings during the period January to June 2017, March/April 2018, and March/April 2019 were attended. Subsequently, meeting minutes and presentations, which had been made available online, were downloaded. Documents (as detailed in Table 1.) were collected, starting with the official documents of the 2012 and 2017 CMPs. Further relevant documents were identified by the snowball method, from documents and interviews.

\section{Data analysis}

All data were analyzed using varieties of qualitative content analysis adapted to the particular characteristics of the data, and following a broadly abductive procedure, as described by Brinkman (2014). Interview data were subjected to broad thematic content analysis following a deductive-theninductive approach. Initial themes were developed from the conceptual framework and related to (i) how the costs and benefits of the plan were conceptualized in planning, for the 10 decision-making-focused interviews, and (ii) to how costs and benefits would be experienced by fishers, in the other 11 interviews. Initial themes were refined, and further themes were developed inductively, from engagement with the material. Meeting notes from non-participant observation were filtered for content relevant to the interests of the research project and then subjected to similar processes to the interview data. Five dominant themes emerged, and are presented in the "Principles behind decision-making" section.

Document analysis for the technical data-set was analyzed using a question-driven text analysis, where the materials were interrogated in relation to two central principles of utilitarianism: whether the use of metrics and formal planning decisions in the technical documents represented (i) a prioritization of monetary values over other values, and (ii) aggregate measures of benefit over questions of distribution.

\section{Results}

\section{Principles behind decision-making}

The guiding principles that emerged from the thematic analysis were grouped into five categories: (i) economic cost/benefit, (ii) aggregate measures, (iii) multiple lines of defense and use of natural processes, (iv) political buy-in, and (v) ecological and cultural benefits. These are described below:

(i) Economic cost/benefit - there was a general agreement in the data that the major benefits of restoration and protection would be economic, understood broadly. This included benefits to a few major industries, multiplier effects from spending on the construction of projects, and the protection of built property generally. Major industries targeted included navigation, oil and gas, and to a lesser extent fishing. The prevention of damage to the city of New Orleans was a common theme in relation to the protection of property. This was often related to hurricane damage, especially with reference to Hurricane Katrina.

(ii) Aggregate measures - the economic benefits of the plan were generally conceptualized at the aggregate level, meaning benefit to the entire coastal region or the state generally. There was acknowledgement that there would be distributional effects, especially negatively 
Table 1 Methods and techniques used to collect and analyze the data in the two data-sets

\begin{tabular}{|c|c|c|c|}
\hline Method & Data source(s) & Data collection & Data analysis \\
\hline \multicolumn{4}{|l|}{ Qualitative data set } \\
\hline Interviews & $\begin{array}{l}\text { - } 10 \text { planning scientists, planning } \\
\text { administrators, and academics }\end{array}$ & $\begin{array}{l}\text { Audio recordings and hand-written } \\
\text { notes }\end{array}$ & Qualitative thematic coding \\
\hline Non-participant Observation & $\begin{array}{l}\text { - Public hearings for } 2017 \text { CMP } \\
\text { - Meetings of LDWF Oyster, Shrimp } \\
\text { and Crab Task Forces } \\
\text { - Meetings of CPRA board and } \\
\text { governor's advisory commission on } \\
\text { coastal restoration } \\
\text { - One summit on coastal restoration } \\
\text { sponsored by America's Wetland } \\
\text { Foundation }\end{array}$ & $\begin{array}{l}\text { Hand-written notes and audio } \\
\text { recordings }\end{array}$ & Qualitative content analysis (QCA) \\
\hline Video analysis & $\begin{array}{l}\text { - Meetings of Sub-committees of } \\
\text { Louisiana legislature }\end{array}$ & Hand-written notes & QCA \\
\hline Document analysis & $\begin{array}{l}\text { - Transcripts of public hearings on } \\
2017 \text { CMP } \\
\text { - Public comments on } 2012 \text { and } \\
2017 \text { CMP }\end{array}$ & Downloaded text documents & QCA \\
\hline \multicolumn{4}{|l|}{ Technical data set } \\
\hline Document analysis & $\begin{array}{l}\text { Documents recording the deploy- } \\
\text { ment of planning tools and models } \\
\text { for the } 2017 \text { CMP: } \\
\text { - A landscape model (CPRA, 2017a; } \\
\text { Meselhe et al., 2015; Meselhe } \\
\text { et al., 2016; White et al., 2016), } \\
\text { which predicts physical changes to } \\
\text { the coast as a result of restoration } \\
\text { projects } \\
\text { - An ecosystem model (CPRA, } \\
\text { 2017a; Mutsert et al., 2017b), } \\
\text { which predicts changes in the } \\
\text { biomass of various species } \\
\text { - A planning tool (Groves et al., } \\
\text { 2017), which describes the use of } \\
\text { metrics and an objective function } \\
\text { to generate project alternatives } \\
\text { - A socio-economic study commis- } \\
\text { sioned by the CPRA (REC and EE, } \\
\text { 2016), which predicts the impacts } \\
\text { of projects on indicators like GDP } \\
\text { and jobs } \\
\text { - Peer-reviewed ecological studies, } \\
\text { which predict the impacts of cer- } \\
\text { tain projects on fisheries (especially } \\
\text { (Adamack et al., 2012; Brown, } \\
\text { 2017; de Mutsert et al.,2017a, b; } \\
\text { Rozas \& Minello, 2011; Soniat } \\
\text { et al., 2013; Wang et al., 2017)) }\end{array}$ & Downloaded text documents & $\begin{array}{l}\text { Question-driven qualitative text } \\
\text { analysis }\end{array}$ \\
\hline
\end{tabular}

impacting some fishers. These were seen as largely unavoidable, rather than something that would be ameliorated in planning. There were a number of interviewees who presented this lack of attention to distribution as a weakness of the plan (iii) Multiple lines of defense and use of natural processes - other major principles guiding the type and placement of projects were that they should follow a "multiple lines of defense" strategy and use natural processes. The former refers to the principle of ensuring there are multiple barriers to incoming storm surge and large 
waves: from barrier islands, to wetlands, to levees, and home elevations and flood-proofing. The use of natural processes referred, in particular, to the use of sediment diversions for restoration. This was variously spoken of in terms of "reconnecting the river" or "putting the river to work."

(iv) Political buy-in — the principle of "awarding" projects to parishes across the coast in order to maintain the support of local governments was apparent. Much CPRA board meeting time was devoted to the discussion of particular projects raised by board members from the concerned parishes. This principle was alluded to by a number of the interviewees, but is also supported by the work of Eric Nost (2018).

(v) Ecological and cultural benefits - finally, the ambition to address cultural, social, and ecological needs was recognized by many interviewees, and was spoken about in multiple meetings of the CPRA. However, these were generally raised as points of critique toward the plan, in that the CMP nominally aims to address these, but has failed to do so concretely.

Three of these principles, (i) the focus on economic benefit, (ii) the focus on aggregate measures, and (v) the exclusion of other values, provide evidence that supports the hypothesis that utilitarianism underlies the CMP. Principles (iii) and (iv) provide further detail on how decisions are made, but neither support nor contradict the hypothesis. Both distributing projects across the coast to gain political buy-in, and using a multiple lines of defense strategy and natural processes are, in principle, compatible with a utilitarian approach, which seeks to maximize the aggregate economic benefit from restoration investment.

\section{Analysis of technical documents}

Technical documents were examined using question-driven qualitative document analysis, focused on confirming or denying the presence of two key principles of utilitarianism. The findings are described below.

\section{Maximizing economic benefit to the exclusion of other values}

Restoration planning and brown shrimp We saw in "Restoration in Louisiana's Coastal Master Plan" section that the primary criterion for restoration is to maximize land in a cost-effective manner. Other metrics are used selectively to ensure that certain valuable features of the coastal environment are preserved or improved. In the case of sediment diversions, scenarios were tested using metrics for the impact on important commercial species. It was found that scenarios that would maximize land would lead to significant declines in the area of habitat suitable for brown shrimp (Groves et al., 2017). Conversely, scenarios aimed at maximizing habitat for brown shrimp would reduce the overall amount of land built. A compromise scenario was chosen, which would preserve brown shrimp habitat at current levels and maximize land given that constraint (Groves et al., 2017). Overall, modelling documents reveal, the chosen restoration scenario maintains the biomass stocks of commercial species at approximately current levels or increases them (Mutsert et al., 2017a). The socio-economic report commissioned by the state uses the biomass outputs from ecosystem modelling to predict impacts in terms of GDP and jobs. This report shows that both of these indictors will be improved over the 50-year life of the project (REC and EE, 2016). In this case, biomass metrics were used to ensure the continued economic contribution from fishing commercial species.

Use of non-economic metrics On the other hand, indicators for certain non-commercial species, like brown pelicans, showed big decreases, but no adjustments were made to the chosen alternative (Groves et al., 2017). Similarly, the impacts of various scenarios on a range of non-monetary metrics were generated, for example, for the use of natural processes and for the protection of buildings of historic importance, but there is no evidence that these influenced the chosen scenario in the way the metric for brown shrimp habitat did (Groves et al., 2017). This provides further evidence that the CMP maintains an economic focus to the exclusion of other values.

Economic criteria in protection planning Whereas land area is the decision driver in restoration planning, reduction in $\mathrm{EAD}$ is the decision driver in protection planning. EAD is measured in dollars and includes damage caused to buildings and infrastructure but also "lost income, lost sales, lost rents, and relocation expenses" (Fischbach et al., 2012), this is combined with a cost-effectiveness provision, which means that protection planning essentially amounts to a cost-benefit approach, a hallmark of the utilitarian approach in environmental decision-making (Boda \& Faran, 2018).

\section{The use of aggregate measures and neglect of distributional issues}

Restoration planning and brown shrimp By introducing freshwater into saltwater or brackish areas, diversions will destroy and relocate the habitats for certain commercial species in certain areas, including shrimp and oysters. Modelling shows that the Mid-Breton sound diversion will damage the habitat for brown shrimp and oysters in the bay [6] and similar results are expected for the Mid-Barataria diversion [7]. The state-commissioned socioeconomic report states 
that there will be localized and temporary negative impacts to GDP and jobs [9], nevertheless this scenario was selected, with no measures to address these distributional issues.

Social vulnerability index Similarly, a social vulnerability index was generated to identify the impacts of projects on vulnerable communities. Though certain vulnerable communities were found to experience greater damage after 50 years of the CMP than the scenario with no projects, this did not actively influence the outcome of the final plan (Groves et al., 2017; Reed et al., 2017).

Low-income families A criterion to provide protection for low-income families was tested but did not influence the chosen scenario. It was modelled in a way that restricted the overall size of the program (O'Byrne, 2020), and so the judgement of the decision-makers was that this parameter was "very restrictive" and so, this measure to prioritize lowincome families was dropped (Speyrer \& Woodard, 2017b) p. 47. They argued, "constraining LMI (Low and Medium Incomes) as a decision factor would potentially exclude high income properties which are likely more cost-effective to mitigate due to their higher property values" (Speyrer \& Woodard, 2017b) p. 41. Aggregate monetary benefit is again prioritized over addressing potential distributional issues.

Together the presence of these two principles provides further evidence to support the argument that utilitarianism underlies the decision-making process in the CMP. The next section will discuss the potential impacts of pursuing such an approach. The discussion that follows will motivate an argument for pursuing a capability approach as an alternative, and present an outline of such an approach.

\section{Utilitarianism and its impacts}

\section{Distributional issues}

Multiple studies and reports indicate that sediment diversions will result in localized negative impacts; there will be declines of fish stock in certain areas, in particular species, and temporarily at the commencement of operation of the diversions (Adamack et al., 2012; Mutsert et al., 2017a, Mutsert et al., 2017b; Rozas \& Minello, 2011). The CPRA never denies that there will be negative impacts, but nor does it provide an explanation of how those affected might recover or adapt. There are no provisions made in the CMP to assist those who will be negatively affected, and so it seems that recovery will be left up to individuals. This is theoretically coherent with the kind of market-centered utilitarianism identified in the CMP. There is an assumption that a freemarket will distribute the benefits of growth efficiently, allowing those who have been negatively impacted to adapt and recover quickly. If the productive resource is maintained in the long-run, and demand for the product remains, the thinking goes, then harvesting, production, and distribution of that product will necessarily follow. Individuals will have to adapt to changed conditions but a free-market is seen as the best guarantee that they can do so.

Contrary to this assumption, there is contextual and historical evidence to suggest that adaptation will not be so straightforward. A survey found that the kinds of adaptation fishers thought would be necessary to continue fishing would involve measures such as moving to the new productive areas; the modification of vessels; moving to other fisheries; and changing their line of work, and receiving economic help and compensation (Louisiana's Seafood Future, 2019). Similar claims were made by fishers in interviews and in their interactions with the state in public meetings. All of these adaptations will require some existing capital, access to credit, or other adaptive capacities, such as the competence to work in other sectors. If the fishing industry continues to grow, as the modelling suggests, then some fishers will certainly be able to make these adjustments, but certain features of the fishery, and fishing communities involved, suggest that a return to employment will not be smooth or equally distributed. The factors that will affect this process, elaborated below, include wealth, class, ethnicity, language and formal education, and gender.

Because returning to fishing is likely to require investments, fishers' ability to return to employment will depend on levels of current wealth and debt. Looking at these factors in two major fisheries, shrimp and oysters (NOAA, 2018a), we see dynamics that suggest recovery will be unevenly distributed. Shrimpers on average tend to have low incomes, with many failing to break even, but also low levels of formal debt (Bourgeois, 2015), though levels of informal debt mean that actual debt is no doubt higher (Marks, 2012). Shrimp prices have historically been highly unstable, with low prices in the past causing both mass exodus from shrimping (Marks, 2012) and threatened strikes (Baurick, 2018). The most recent available data suggest that incomes in the oyster fishery were higher than for shrimping operations, but there were also higher levels of debt (Banks, 2016). Prices for oysters have tended to be more stable but with some recent disastrous years, brought about by the BP oil spill and freshwater flooding.

There are also class relations within the sector, which overlap with gender, ethnicity, and education levels, all of which are likely to contribute to uneven recovery. For example, deckhands that work as wage laborers on fishing boats have, in times of previous crisis, been the first to be laid off (Marks, 2012). In family-run operations, this can mean substituting their work with unpaid work by family members, including wives and children. Some deckhands in the substantial Vietnamese shrimping community also lack skills in 
the English language (Schewe \& Dutton, 2018). Similarly, many in the fishing communities lack formal education. Formal education and English language skills are important for both accessing compensation and loans, and for finding new employment. Outside of fishing, seafood processors, lowpaid laborers with a high-proportion of women of color and migrant laborers (C. D., 2019; Deliberto \& Schafer, 2018), have historically been some of the first to be laid off and have got poorer compensation than fishers (Nguyen, 2017).

\section{Losses beyond income}

Beyond the poor distributional effects, fishers are also likely to suffer losses that utilitarianism does not pay attention to, i.e., losses beyond income. Interviewees and participants in meetings with the state mentioned the following, in particular:

- People might have to relocate, losing attachments to places that their family might have lived in for generations.

- If whole communities are forced to relocate, there is a loss of community and a particular culture.

- If people lose their way of life, there are impacts, for example, in terms of mental health.

- There are losses if children leave school earlier, or wives lose access to independent employment.

The above statements are just in relation to changes brought about in seeking for new employment. The transformation of the ecosystem will also potentially lead to certain other losses.

- Land will be lost in some places and gained in others, these could be sacred areas, or areas of traditional or cultural importance.

- Saltwater marsh will change to freshwater marsh, which will bring new species, including different invasive species.

- It seems likely that there will be losses to certain species like brown pelicans (Groves et al., 2017) and bottlenosed dolphins (Garrison et al., 2020; NOAA, 2018b).

Measures have been proposed that would help some fishers, and other negatively affected coastal people, to adapt to restoration related and other environmental disturbances. These include the LASAFE (Louisiana Strategic Adaptations to Future Environments) program, which was developed with federal funding in response to Hurricane Isaac in 2012. This is a broad adaptation plan available to the 6 parishes affected by the hurricane but not all parishes affected by restoration. Another measure came about due to a recently completed Army Corps environmental impact statement; the state has proposed up to $\$ 300$ million to help fishers and others adapt to changed conditions due to restoration. These are welcome efforts to address the problems coastal people face. However, the LASAFE program is limited in coverage and funding and not targeted to the specific needs created by restoration. Compensation schemes which come after the fact have also been historically problematic, for example, they can recreate inequalities when those with greater access to resources are better able to access them (Nguyen, 2017). While in practice, people in Louisiana may not be left totally to their own devices to adapt, this is still the assumption underlying the approach in the CMP. Instead of relying on a range of partial, piecemeal, and expost schemes, these concerns should be integrated systematically and from the start. Using a capability approach is a comprehensive way of doing just this.

\section{Discussion}

\section{Capability as an alternative to utilitarianism in the CMP}

The uneven distribution of recovery and the losses in terms of non-economic values of nature, identified in the previous section, are precisely the kinds of problems that the monetary valuation of nature has been found to create (GómezBaggethun \& Ruiz-Pérez, 2011). It is possible that a betterdesigned multi-criteria decision-making process could have avoided these problems. There are numerous suggestions in the literature for how to improve MCDA processes (Martin et al., 2018; Marttunen et al., 2015; Saarikoski et al., 2016). Even within the CMP itself, metrics for non-economic values and distributional issues were developed for the CMP. For example, there was a metric for brown pelican habitat, which modelled impacts of projects on this non-commercial species, but negative outcomes in terms of this metric had no influence on the final CMP (Groves et al., 2017). Similarly, in the planning of protection projects, a metric for the impact on low-income families was modelled (Groves et al., 2017; Speyrer \& Woodard, 2017b). However, this was not used in restoration planning.

Rather than focus on improving the multi-criteria planning in its current form, the argument in this article posits that these exclusions are systemic, arising from the implicit reliance on utilitarianism, rather than the results of accidental oversight. This necessitates recourse to theoretical critique, to establish a basis for decision-making, which can supersede utilitarianism in the CMP. The capability approach, as propounded by Amartya Sen and others (Robeyns, 2005, 2017; Sen, 2001), provides such an alternative. The following section presents an argument for why the capability approach is an improvement on utilitarianism; 
how it might be operationalized in this case, and some barriers to the latter.

\section{The capability approach}

Amartya Sen, in developing the capability approach, has engaged in sustained theoretical critique of utilitarianism in economic decision-making (Sen, 1979, 2001). Sen situates welfare economics in the tradition of liberal philosophy to make his point. The aim of liberal theory, he explains, is to improve people's freedom. Sen points out that in utilitarian thinking income is simply a means toward achieving freedom. It is strange, therefore, to treat it as an end in itself. Would it not make more sense, Sen argues, to make the expansion of freedom the ends of decision-making more directly?

Sen's conception of freedom is positive (Berlin, 2017), meaning that freedom is about the ability to live a good life. Sen uses the concept of capabilities to elaborate this. According to Sen, capability can be considered the ability to lead a life that one has reason to value (Sen, 2001). Ingrid Robeyns (2005) describes capabilities as "substantive opportunities." People have a high level of freedom if they have the substantive opportunity to be healthy, well-nourished, part of a community, to have a job they find meaningful, and so on. Capabilities are closely related to, but distinct from, functionings. Functionings are the actual outcomes that people achieve, the "doings and beings"; the state of being healthy and well nourished, participating in a community, enjoying a healthy natural environment, and so on. For Sen, public decision-making should aim to directly expand the freedom of the public, understood as capabilities and functionings.

In making this switch to a focus on freedom, Sen tackles the two key problems with utilitarianism. The first is the question of distribution, which has for a long time been a point of discussion in welfare economics (Kaplow \& Shavell, 2000; Sen, 1979, 1999b; Tinbergen, 1957). When freedom is understood in terms of capabilities, it becomes clear that the best way of achieving a freer society is to start with expanding the capabilities of the least free. Secondly, from the perspective of capabilities, we can consider both utility and non-utility concerns, so long as they contribute to what individuals reasonably consider valuable. In environmental decision-making, this allows for consideration of people's multiple values for nature. Though capabilities refer to humans, taking a capabilities approach does not mean we reject environmental limits (Rockström et al., 2009), it merely provides a framework for evaluating what we mean by a good society in relation to these limits. Compared to the utilitarian approach, the environment is considered for its contribution to human capabilities rather than for its contribution to GDP (Sen, 2004). Whereas the utilitarian approach tends to recreate inequalities, as we saw above, the capability approach shows that we should value nature, and restoration, not in terms of the resources it provides per se, or in terms of the contribution of the resources to GDP, but in their contribution to human freedoms, starting with the freedoms of the worst-off.

\section{Operationalizing capabilities expansion}

Operationalizing the capability approach in coastal restoration will require two steps. Firstly, an evaluative framework for judging alternatives in terms of their impacts on capabilities must be constructed. The utilitarian approach provides a consistent and objective means on which to base decisions, which is relatively simple. The capability approach can be operationalized in an equally objective and consistent manner, though it requires larger informational inputs to take account of distributional effects and the various ways in which the environment contributes to people's lives (Sen, 1999b). Secondly, this evaluative framework must be translated into metrics that are compatible with modelling, and planning more broadly.

\section{Developing an evaluative framework}

Following a capability approach involves generating an evaluative framework for judging alternative projects and project combinations in terms of their impacts on capabilities and functionings (Sen, 2001). Since a large number of capabilities can be affected by restoration projects, it is important that this framework involves a quantified prioritization or "weighting" of the criteria (Sen, 2001), which represents the aggregated priorities of the affected communities. One binding condition of these processes is that the capabilities of the worst-off should be prioritized (Robeyns, 2017; Sen, 2001). Furthermore, the identification of the full range of relevant capabilities and their weighting should happen with the participation of all the affected parties. In the current case, we can hypothesize, for example, that the maintenance of the economic wellbeing of low-income seafood workers would score relatively highly, whereas the consideration of aesthetic values of non-residents would score lower. This provision would mean that alternatives that ensured that those with lower adaptive capacity were equally capable of returning to work after a disturbance, would be given higher priority than those that did not. However, in practice the precise formulation of these priorities should be settled through a structured and rigorous deliberative process. This social choice process (Sen, 1999b) would also be used to surface and identify non-economic values, like connections to place, cultural artifacts and values, the impact on marine mammals and non-commercial species, and so on. The tools of MCDA (Fancello et al., 2020; Pelenc \& Etxano, 2021) can 
be an excellent approach for operationalizing the capability approach, in line with Sen's own work on social choice (Sen, 1999b).

\section{From evaluative framework to planning: metrics and modelling}

Once the evaluative framework has been developed it must be transformed into a series of metrics to be deployed as selection criteria, and used in conjunction with modelling. Introducing new metrics to reflect the various capabilities involved would require expansion of the informational base for the CMP. For example, there has been a major gap in previous CMPs in terms of understanding the precise nature and magnitude of the impacts from river diversions (Brown, 2017), which needs to be remedied. Another issue is that the current ecological and socio-economic modelling reflects the aggregative utilitarian approach. To overcome this, studies need to be carried out at spatial and temporal scales that can capture the real distributive effects of restoration projects. Similarly, socio-economic studies need to take account of the full range of ways in which nature is reasonably valued by people, which reflect the substantive opportunities that the environment provides to current and future generations. Only when such data is available can metrics representing the prioritized capabilities be properly deployed. Numerous techniques have been developed to represent non-economic values as metrics in decision-making procedures (Convertino et al., 2013). The following are a few examples, though a final list would depend on the evaluative framework that is developed.

Firstly, to deal with questions of distribution, the landscape and biomass models should produce outputs that are sufficiently spatially disaggregated to account for where losses would be felt. This information could then be fed into the socio-economic modelling to generate figures on the impacts in terms of income and jobs. To satisfy the necessity of addressing the capabilities of the worst-off, this data would be overlaid with survey data on socio-economic factors, to identify who is likely to feel the worst effects of restoration projects, and what kinds of losses they are likely to experience.

Secondly, values that are more difficult to quantify than income should be incorporated. A number of metrics like this are already produced for the CMP, for example, a social vulnerability index and a metric indicating protection of historic properties (Reed et al., 2017). However, these are not consistently applied in decision-making. According to the capability approach, these metrics should be developed based on the evaluative framework (Boda, 2018). The method for turning these capabilities into metrics will depend on the capability involved. For example, in relation the cultural values of particular areas, it would be possible to assess areas for their cultural value, in participatory processes, and assign these an index, which could be used in conjunction with the landscape model. Similarly, the importance of community attachment, which could be disrupted due to forced migration, could be represented by thresholds for out-migration.

The outcome of such a process, as it regards particular projects, cannot be determined prior to the development of the evaluative framework. Whether diversions would go ahead or not, for example, cannot be decided beforehand. What can be said is that, if they were to go ahead, there would have to be a large parallel social program to ensure the protection of the capabilities and functionings of those affected, particularly the worst-off. On the other hand, if they were not to go ahead, there would have to be some way of ensuring that environmental goals were also met. For example, studies have shown that in the absence of diversions, the salinity line will continue to move landwards causing further problems for fishers in the future (White et al., 2019).

\section{Challenges in putting a capability approach into practice}

There have been numerous arguments from researchers that the state adjust its approach to planning, many of them less radical than what the present study proposes, but there is no evidence that the state has heeded these arguments (Bethel et al., 2014; Colten, 2016; Colten \& Hemmerling, 2014). This suggests that if capabilities are to become the basis of decision-making, in order to guarantee a fairer and more equitable planning process, we cannot expect that authorities will necessarily take it up in response to rational academic arguments.

Introducing a capability approach would require significant resources, highly involved participatory processes, and a more capacious democratic approach to planning (Fainstein, 2009; Robeyns, 2017). The kind of deliberation necessary to deliver a capability approach is not simply open deliberation over the criteria that should direct planning. This kind of deliberation is already part of the planning process and has not addressed the concerns raised above (Speyrer \& Woodard, 2017a, 2017b). A capability approach requires that everyone affected be represented equally and that real decision-making power be devolved to the process. The process would also be bound by the necessity of prioritizing the capabilities of the worst-off. Installing such rigorous democratic procedures shifts the problem beyond one of planning rationality to the realm of politics. Taking a capability approach, because it deals with questions of distribution, is likely to shift costs from a worst-off social group to a better-off group. But as Sen (1999a) acknowledges, because this kind of distributive outcome is very difficult to achieve 
in a harmonious manner, it will run into problems of "political feasibility" (Sen, 1999a).

Beyond the problem of creating the appropriate institutional arrangements for effective deliberation, Peter Evans points out that Sen underestimates "the extent to which modern market processes might constitute an impediment to the kind of deliberative preference formation that is essential to the expansion of capabilities" (Evans, 2002). It is not so easy to get people to identify and prioritize the capabilities of the worst-off because our values and beliefs are structured by the dominant ideas of the society in which we live. The social values that would allow such a prioritization may have to be dominant in society before a capability approach would be possible to implement.

In sum, there are numerous structural barriers to the realization of a capability approach. This suggests that achieving fairer planning will have to be the subject of political struggle. The state has barely budged from its current approach, even in the face of imminent losses to disadvantaged communities and public criticism. If the state is unwilling to change its approach, it will have to be pushed by the public and civil society to do so (O'Byrne, 2020).

\section{Conclusion}

Multi-criteria-driven restoration planning has the potential to overcome problems associated with monetary valuation. However, the use of multiple criteria alone cannot guarantee this. This study has shown that Louisiana's coastal restoration program, though it uses multiple criteria, recreates two of the major problems associated with the use of monetary valuation. Because of its implicit reliance on economic utilitarianism, it lacks attention to distributional issues and fails to value nature other than in monetary terms. The study has therefore argued that an alternative approach to environmental and economic decision-making, the capability approach, can overcome these issues. In doing so, it argues that restoration should be focused on restoring natural assets that contribute most to the expansion of the freedoms of the worstoff, taken as capabilities, rather than restoring resources to maximize the contribution to GDP. In the present case, this would likely mean: the collection of more spatially and temporally disaggregated data; the participation of all those potentially affected, rigorous and binding participatory decision-making processes, and social spending programs that can guarantee that the worst-off in society will not bear the costs of restoration. The capability approach can thereby be an effective undergirding logic for multi-criteria ecosystem restoration. With that said, implementing a capability approach presents both technical and political challenges. In
Louisiana, it will likely require political action by citizens to realize more equitable decision-making.

Acknowledgements I would like to acknowledge the support of my $\mathrm{PhD}$ supervisors, all those who supported my research in Louisiana, especially the people of Louisiana who sacrificed their time to explain their world to an outsider, and a number of anonymous reviewers.

Funding Open access funding provided by Lund University. The fieldwork for this paper was partially funded by Svenska Sällskapet för Antropologi och Geografi.

Data Availability Not applicable.

Code availability Not applicable.

\section{Declarations}

Ethics approval Not applicable.

Consent to participate All interview participants gave full informed consent.

Consent for publication All interview participants gave full informed consent.

Conflict of interest The author declares no competing interests.

Open Access This article is licensed under a Creative Commons Attribution 4.0 International License, which permits use, sharing, adaptation, distribution and reproduction in any medium or format, as long as you give appropriate credit to the original author(s) and the source, provide a link to the Creative Commons licence, and indicate if changes were made. The images or other third party material in this article are included in the article's Creative Commons licence, unless indicated otherwise in a credit line to the material. If material is not included in the article's Creative Commons licence and your intended use is not permitted by statutory regulation or exceeds the permitted use, you will need to obtain permission directly from the copyright holder. To view a copy of this licence, visit http://creativecommons.org/licenses/by/4.0/.

\section{References}

Adamack AT, Stow CA, Mason DM, Rozas LP, Minello TJ (2012) Predicting the effects of freshwater diversions on juvenile brown shrimp growth and production: a Bayesian-based approach. Mar Ecol Prog Ser 444:155-173

Atkinson AB (1999) The contributions of Amartya Sen to welfare economics. Scand J Econ 101(2):173-190

Atkinson AB (2009) Economics as a moral science. Economica 76:791-804

Banks, P. B., Steve; Chapiesky, Katie; Isaacs, Jack. (2016). Louisiana Oyster Fisheries Management Plan. Retrieved from Louisiana Department of Wildlife and Fisheries, Baton Rouge, Louisiana:

Baurick, T. (2018). Louisiana shrimpers consider strike as prices plummet. Nola.com/Times Picayune. Retrieved from https://www.nola. com/news/environment/article_c3955de4-3fdb-5c10-85ec-2d00c b4694c3.html 
Bayraktarov E, Saunders MI, Abdullah S, Mills M, Beher J, Possingham HP, Lovelock CE (2016) The cost and feasibility of marine coastal restoration. Ecol Appl 26(4):1055-1074

Berlin I (2017) Two concepts of liberty. In: Miller D (ed) Liberty Reader. Routledge, New York, pp 33-57

Bethel MB, Brien LF, Esposito MM, Miller CT, Buras HS, Laska SB, Parsons Richards C (2014) Sci-TEK: a GIS-based multidisciplinary method for incorporating traditional ecological knowledge into Louisiana's coastal restoration decision-making processes. J Coastal Res 30(5):1081-1099

Boda C, Faran T (2018) Paradigm fund? Immanent critique to tackle interdisciplinarity and normativity in science for sustainable development. Sustainability 10(10):3805

Boda CS (2018) From economic choice to social choice in coastal management: a critical assessment of the use of cost-benefit analysis in the evaluation of an erosion control project in Flagler County, Florida, U.S.A. Ocean Coast Manag 162:85-99. https://doi.org/ 10.1016/j.ocecoaman.2017.09.017

Bourgeois, M. L., Lisa; Lightner, Julia; Marx, Jeff; Semon, Katie. (2015). Louisiana Shrimp Fisheries Management Plan. Retrieved from Louisiana Department of Wildlife and Fisheries, Baton Rouge, Louisiana:

Brinkmann S (2014) Doing without Data. Qual Inq 20(6):720-725

Brown, G. (2017). Uncertainties in the forecasted performance of sediment diversions associated with differences between "Optimized" diversion design criteria and the natural crevasse-splay sub-delta life-cycle. Paper presented at the AGU Fall Meeting Abstracts.

C. D. (2019). Seafood Workers Alliance. Retrieved from http://nolaw orkers.org/2019/04/13/seafood-workers-alliance/

Colten C (2016) Environmental management in coastal Louisiana: a historical review. J Coastal Res 33(3):699-711

Colten, C., \& Hemmerling, S. (2014). Social impact assessment methodology for diversions and other Louisiana coastal master plan restoration and protection projects. Retrieved from Water Institute of the Gulf, Baton Rouge, Louisiana:

Convertino M, Baker K, Vogel J, Lu C, Suedel B, Linkov I (2013) Multi-criteria decision analysis to select metrics for design and monitoring of sustainable ecosystem restorations. Ecol Ind 26:76-86

CPRA. (2017a). 2017 Coastal Master Plan appendix c: modeling chapter 4 - model outcomes and interpretations. Retrieved from Coastal Protection and Restoration Agency, Baton Rouge, Louisiana:

CPRA. (2017b). Louisiana's Comprehensive Master Plan for a Sustainable Coast. Retrieved from Coastal Protection and Restoration Authority of Louisiana., Baton Rouge, Louisiana. :

Day JW, Lane RR, D'Elia CF, Wiegman AR, Rutherford JS, Shaffer GP, Kemp GP (2018) Large infrequently operated river diversions for Mississippi delta restoration. Mississippi Delta Restoration. Springer, Cham, pp 113-133

de Mutsert K, Lewis K, Buszowski J, Steenbeck J, Milroy S (2017a) 2017 Coastal Master Plan Attachment C3-20: Ecopath with Ecosim (EwE). Retrieved from CPRA of Louisiana, Baton Rouge, Louisiana

de Mutsert K, Lewis K, Milroy S, Buszowski J, Steenbeek J (2017b) Using ecosystem modeling to evaluate trade-offs in coastal management: effects of large-scale river diversions on fish and fisheries. Ecol Model 360:14-26

Deliberto, M., \& Schafer, M. (2018). Temporary foreign labor and sugar in Louisiana. Louisiana Agriculture, 61(2).

Dufour S, Piégay H (2009) From the myth of a lost paradise to targeted river restoration: forget natural references and focus on human benefits. River Res Appl 25(5):568-581

Ellen IG, Yager J, Hanson M, Bosher L (2016) Planning for an uncertain future: can multicriteria analysis support better decision making in climate planning? J Plan Educ Res 36(3):349-362
Evans P (2002) Collective capabilities, culture, and Amartya Sen's development as freedom. Stud Comp Int Dev 37(2):54-60

Fainstein, S. S. (2009). Planning and the just city. In Searching for the just city (pp. 39-59): Routledge.

Fancello G, Congiu T, Tsoukiàs A (2020) Mapping walkability. A subjective value theory approach. Socio-Econ Plan Sci 72:100923

Faran, T. (2010). Synthesis of the discourses on development and sustainable development (Deliverable 4, GLOBIS Framework 7 EU funded project ). Retrieved from LUND University,

Fischbach JR, Johnson DR, Ortiz DS, Bryant BP, Hoover M, Ostwald J (2012) Coastal Louisiana risk assessment model (0833077082). Retrieved from RAND corporation, Santa Monica, California

Garrison, L. P., Litz, J., \& Sinclair, C. (2020). Predicting the effects of low salinity associated with the MBSD project on resident common bottlenose dolphins (Tursiops truncatus) in Barataria Bay, $L A$. Retrieved from NOAA,

Giosan L, Syvitski J, Constantinescu S, Day J (2014) Climate change: protect the world's deltas. Nature 516(7529):31-33

Gómez-Baggethun E, Ruiz-Pérez M (2011) Economic valuation and the commodification of ecosystem services. Prog Phys Geogr 35(5):613-628

Groves DG, Panis T, Sanchez R (2017) 2017 Coastal Master Plan, appendix d: planning tool. Retrieved from Coastal Protection and Restoration Authority, Baton Rouge, Louisiana

Kaplow L, Shavell S (2000) Fairness versus welfare. Harv Law Rev 114:961

Kolinjivadi V, Gamboa G, Adamowski J, Kosoy N (2015) Capabilities as justice: analysing the acceptability of payments for ecosystem services (PES) through 'social multi-criteria evaluation.' Ecol Econ 118:99-113

Lewis, J. A., \& Ernstson, H. (2017). Contesting the coast: ecosystems as infrastructure in the Mississippi River Delta. Progress in Planning, Dec 1.

Liu Z, Cui B, He Q (2016) Shifting paradigms in coastal restoration: six decades' lessons from China. Sci Total Environ 566:205-214

Louisiana's Seafood Future. (2019). Findings Report 2019. Retrieved from Louisiana Seagrant, Baton Rouge: https://static1.squar espace.com/static/5c311daff2e6b1bd0e619a75/t/5d9bd06ec 7 a1c315f1f8599e/1570492538471/LSF-FindingsReport2019. pdf. Accessed 22 Apr 2020

Marks B (2012) The political economy of household commodity production in the Louisiana shrimp fishery. J Agrar Chang 12(2-3):227-251

Martin D, Mazzotta M (2018) Non-monetary valuation using multicriteria decision analysis: sensitivity of additive aggregation methods to scaling and compensation assumptions. Ecosyst Serv 29:13-22

Martin DM, Lyons JE (2018) Monitoring the social benefits of ecological restoration. Restor Ecol 26(6):1045-1050

Martin DM, Mazzotta M, Bousquin J (2018) Combining ecosystem services assessment with structured decision making to support ecological restoration planning. Environ Manage 62(3):608-618

Marttunen M, Mustajoki J, Dufva M, Karjalainen TP (2015) How to design and realize participation of stakeholders in MCDA processes? A framework for selecting an appropriate approach. EURO Journal Decis Process 3(1):187-214

Meselhe E, White E, Brown S, Wang Z (2015) Coastal Ecosystem Integrated Compartment Model (ICM): Modeling Framework. Paper presented at the AGU Fall meeting, San Francisco, California

Meselhe E, White E, Wang Y (2016) Attachment C3-24: Integrated Compartment Model Uncertainty Analysis. Retrieved from CPRA, Baton Rouge, Louisiana

Nguyen, H. V. (2017). Disasters, settlements and the homeland: Vietnamese American experiences of white supremacy in New Orleans. 
NOAA. (2018a). Table: Landings, 2018, Louisiana, All Species: National Oceanic and Atmospheric Administration. https://foss. nmfs.noaa.gov/apexfoss/f?p=215:200:::NO::.: Accessed $19 \mathrm{Feb}$ 2020

NOAA. (2018b). Waiver of Requirements Under Sections 101(a) and 102(a) of the Marine Mammal Protection Act (MMPA) for the Mid-Barataria Sediment Diversion, the Mid-Breton Sound Sediment Diversion, and Calcasieu Ship Channel Salinity Control Measures Projects Federal Register

Nost, E. (2018). Programming adaptation: how modeling informs environmental policy in Louisiana's Coastal Master Plan: the University of Wisconsin-Madison.

O'Byrne D (2020) No more water, but fire next time: the conflict between environmental aims and social claims in Louisiana's post-Katrina coastal planning. Lund University, Lund, Sweden

Ortega Landa, R. (2004). Amartya Sen: utilitarianism, ethics and public policy. Revista Latinoamericana de Desarrollo Económico(2), 149-152.

Pelenc J, Etxano I (2021) Capabilities, ecosystem services, and strong sustainability through SMCE: the case of Haren (Belgium). Ecol Econ 182:106876

REC and EE. (2016). Basin-wide socio-economic analysis of four proposed sediment diversions. Final Report to the Louisiana Coastal Protection and Restoration Authority in Fulfillment of Task 3.5 of the Scope of Work, CPRA Contract No. 2053-14-27, Task Order 1. Retrieved from Earth Economics, Baton Rouge, Louisiana: https:// drive.google.com/file/d/0ByzlUWI76gWVdUpvMGdrTFlOTkk/ view. Accessed 22 Apr 2020

Reed D, Hijuelos A, Hemmerling S, White E, Fischbach JR (2017) 2017 Coastal Master Plan Attachment C4-11: Metrics. Retrieved from CPRA, Baton Rouge, Louisiana

Robeyns I (2005) The capability approach: a theoretical survey. J Human Dev Capabil 6(1):93-117

Robeyns, I. (2017). Wellbeing, freedom and social justice: the capability approach re-examined: Open Book Publishers.

Rockström, J., Steffen, W., Noone, K., Persson, Å., Chapin, F. S., Lambin, E. F., Schellnhuber, H. J. J. n. (2009). A safe operating space for humanity. 461(7263), 472-475.

Rozas LP, Minello TJ (2011) Variation in penaeid shrimp growth rates along an estuarine salinity gradient: implications for managing river diversions. J Exp Mar Biol 397(2):196-207

Saarikoski H, Mustajoki J, Barton DN, Geneletti D, Langemeyer J, Gomez-Baggethun E, Santos R (2016) Multi-Criteria decision analysis and cost-benefit analysis: comparing alternative frameworks for integrated valuation of ecosystem services. Ecosyst Serv 22:238-249

Schewe RL, Dutton C (2018) NOAA fishery observers and Vietnamese American fishers in the Southeastern US. Mar Policy 96:145-151

Sen A (1979) Utilitarianism and welfarism. J Philos 76(9):463-489

Sen A (1999a) On ethics and economics. OUP Catalogue, New York

Sen A (1999b) The possibility of social choice. Am Econ Rev 89(3):349-378
Sen A (2001) Development as freedom. Oxford Paperbacks, New York Sen, A. (2004). Why we should preserve the spotted owl. London review of books, 26(February).

Solow R (1993) An almost practical step toward sustainability Resources Policy: Invited Lecture on the Occasion of the Fortieth Anniversary of Resources for the Future. Resources and Conservation Center, Washington, DC, pp 162-172

Soniat, T. M., Conzelmann, C. P., Byrd, J. D., Roszell, D. P., Bridevaux, J. L., Suir, K. J., \& Colley, S. B. J. J. o. S. R. (2013). Predicting the effects of proposed Mississippi River diversions on oyster habitat quality; application of an oyster habitat suitability index model. $32(3), 629-638$.

Speyrer N, Woodard A (2017) 2017 Coastal Master Plan: attachment G1: public hearing transcripts. Retrieved from Coastal Protection and Restoration Authority, Baton Rouge, Louisiana

Speyrer N, Woodard A (2017) 2017 Coastal Master Plan: attachment G3: framework development team. Retrieved from Coastal Protection and Restoration Authority, Baton Rouge, Louisiana

Syvitski JP, Kettner AJ, Overeem I, Hutton EW, Hannon MT, Brakenridge GR, Giosan L (2009) Sinking deltas due to human activities. Nat Geosci 2(10):681-686

Tessler Z, Vörösmarty C, Grossberg M, Gladkova I, Aizenman H, Syvitski J, Foufoula-Georgiou E (2015) Profiling risk and sustainability in coastal deltas of the world. Science 349(6248):638-643

Tinbergen J (1957) Welfare economics and income distribution. Am Econ Rev 47(2):490-503

Wang H, Chen Q, La Peyre MK, Hu K, La Peyre JF (2017) Predicting the impacts of Mississippi River diversions and sea-level rise on spatial patterns of eastern oyster growth rate and production. Ecol Model 352:40-53

White E, Meselhe E, McCorquodale A, Couvillion BR, Dong Z, DukeSylvester SM, Wang Y (2016) 2017 Coastal Master Plan attachment C3-22: Integrated Compartment Model (ICM) Development. Retrieved from CPRA, Baton Rouge, Louisiana

White ED, Meselhe E, Reed D, Renfro A, Snider NP, Wang Y (2019) Mitigating the effects of sea-level rise on estuaries of the Mississippi Delta Plain using river diversions. Water 11(10):2028

Wright, L. D., Syvitski, J., \& Nichols, C. R. (2019). Sea level rise: recent trends and future projections. In Tomorrow's coasts: complex and impermanent (pp. 47-57): Springer.

Zhang Y, Yang Y, Chen Z, Zhang S (2020) Multi-criteria assessment of the resilience of ecological function areas in China with a focus on ecological restoration. Ecol Indic 119:106862

Publisher's note Springer Nature remains neutral with regard to jurisdictional claims in published maps and institutional affiliations. 